\title{
THE INSECTS AND PLANTS OF A STRIP OF NEW JERSEY COAST ${ }^{1}$
}

\author{
By Harry B. Weiss and Erdman West
}

New Brunswick, N. J.

\section{Introduction.}

This paper deals with the insects and plants of a section of the maritime region of New Jersey and is the fourth of a series of reports on surveys which have been made in different faunal areas of New Jersey.

\section{Acknowledgments.}

Identification of the various species of insects collected during the survey were made by the following entomologists to. whom we are greatly indebted. Hymenoptera, Mr. H. L. Viereck; Diptera, Mr. C. W. Johnson; Coleoptera, Mr. C. A. Frost; Hemiptera, Mr. H. G. Barber; Lepidoptera, Mr. Carl Heinrich and Mr. Wm. Schaus; Cicadellidæ, Mr. C. E. Olsen; Formicidæ, Mr. M. R. Smith; Odonata, Mr. Wm. T. Davis; Orthoptera, Dr. Henry Fox.

\section{The New Jersey Sea Coast}

The maritime region of New Jersey extends along the coast from Sandy Hook to Cape May and includes the beach and its adjoining sand hills. The beaches are narrow, sandy strips often separated from each other by inlets and from the upland by bays, and channels fringed by tide-marsh or salt meadow. According: to the "Annual Report of the State Geologist of New Jersey" for 1885, the beaches "are sand bars of considerable magnitude, which have been formed at a greater or less depth by currents depositing sediment under favorable conditions and subsequently brought above water by the waves, as at the present day, or: perhaps in some cases by the changes of sea level which have

${ }^{1}$ Journal New York Entomological Society, vol. xxx, pp. I69-I90; Journal New York Entomological Society, vol. xxxii, pp. 93-I03; Ecology, vol. v, pp. 24I-253. 
evidently occurred in Quarternary time." Once above water, the particles of sand are carried by the wind and meeting some obstacle out of reach of the tide, are in time built up into dunes or sand hills. After the primary beaches are formed, various agencies combine to change their original extent. "On one side they might be worn away by storms and tidal currents, on another added to by the same agencies and finally they might be greatly extended in course of time by the action of currents running in a constant direction along their shores and depositing sediment at one of their extremeties, as happens now at the point of Sandy Hook, and the south ends of most of the beaches at the inlets."

The beach islands consist of fine white sand which is mobile in places. Dried by the sun and wind, the sand is blown inward or oceanward. The prevailing winds blow toward the ocean and as the sand dries it is blown into the water to be hurled back again by the waves. If the wind is from the ocean for some time, sand hills are formed. Small obstacles sufficient to lessen the force of the wind may serve as the starting point of a dune. Such dunes may form and reform with every action of the wind. At Seaside Park, the shifting was quite pronounced and the contour of the line of dunes next to the ocean changed frequently.

Behind the ocean line of dunes, the shapes of the smaller dunes changed infrequently or not at all. Where vegetation occurs on the beaches such plants catch and hold the sand and dunes are formed rapidly. The beaches vary in width from a few rods to a half-mile and in elevation average only a few feet above high tide. The dunes formed by winds and tides generally reach a height of from fifteen to twenty-five feet.

\section{The Surveyed Area.}

The surveyed area consists of about ten acres in the form of a strip running from the Atlantic Ocean to Barnegat Bay, across Island Beach at a point about one mile below Seaside Park, and just above the Island Beach Life Saving Station. The exact location is indicated on the accompanying map. Temperature and moisture records were not kept, but climatolo- 
gical data for the coastal section in which the survey was made, can be obtained from the publication of the United States Weather Bureau, entitled "Summary of the Climatological Data for the United States by Sections," Reprint of Section 99, The Southern Interior and Sea Coast of New Jersey.

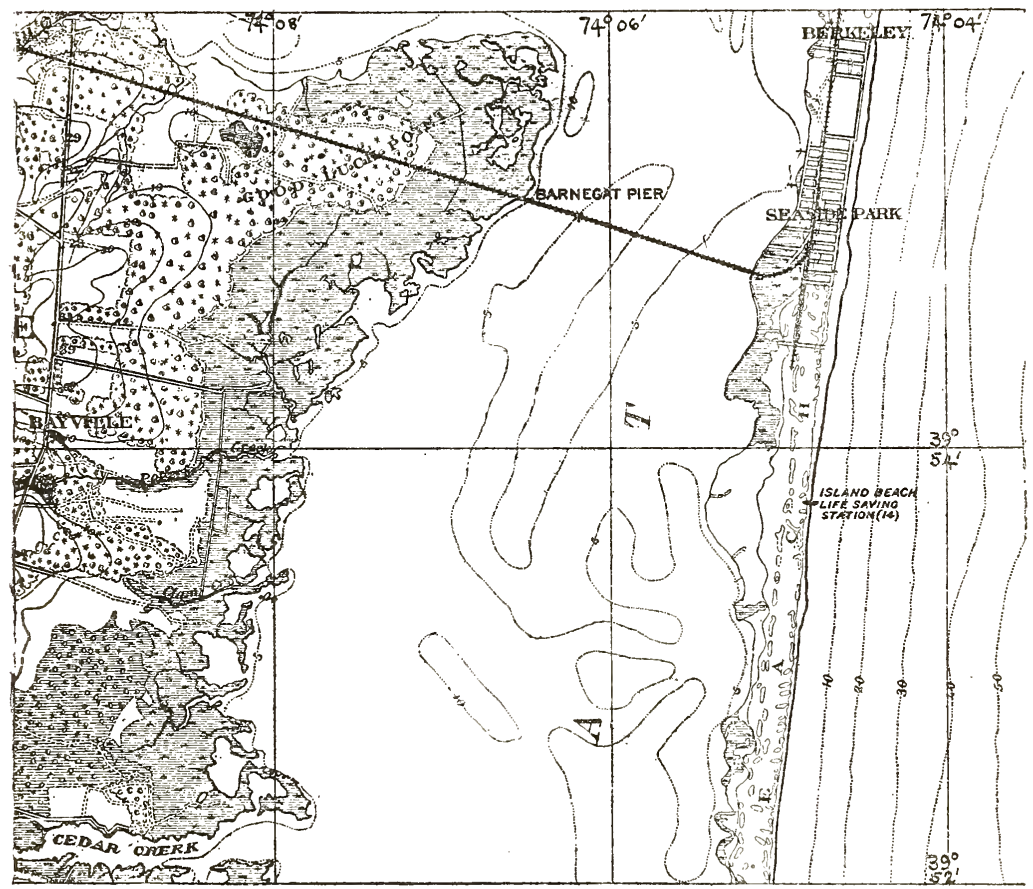

Fig. 1. Map of a portion of the New Jersey coast. The surveyed area adjoins the Island Beach Life Saving Station.

Island Beach from Seaside Park south to Barnegat Inlet is almost the only piece of natural beach left along the New Jersey coast. On account of the absence of a roadway, it has remained "undeveloped" and as such is free from bungalows, cottages, cement walks, real estate agents, swarms of bathers and the amusements supplemental thereto. It is probably only a question of time before it will be levelled, graded and cut up into building lots. 
Collections were made at about ten-day intervals from the very beginning to the end of the insect seasons. All methods were employed and everything was collected. Some night collecting was done also. The area under consideration contained several shallow basins and wet places due to arms of the bay which extended toward the Atlantic Ocean, but little attention was paid to these areas and their comparatively luxurient vegetation, as it was thought desirable to limit the study to the strictly sea coast type. Insects found in "wash-up" along the shore, although collected, are not included in this report unless they are species which normally inhabit the beach and act as scavengers or in other capacities.

Although the flora of the area can be divided into parallel zones, it is necessary to consider the insects as a single group, partly on account of the comparative smallness of the surveyed territory and partly because many species exhibited no tendency to connect themselves exclusively with certain types of vegetation. Species constantly inhabiting various parts of the area will be mentioned in the text.

\section{The Vegetation of the Surveyed Area.}

The flora of this area is divided more or less distinctly into bands or zones parallelling the ocean and bay shore lines. The best way to discuss the vegetation is to take each of these groups in order as they occur, beginning at the ocean shore line. As no collections were made in the water, the only clue we had to the algæ present was the remnant in the wash. This consisted almost entirely of sea lettuce (Ulva sp.) and a brown strap-like kelp. From the edge of the water to the base of the dunes, the sand was devoid of plant life, but about one-half way up the dunes, there appeared an occasional plant of seaside spurge (Euphorbia polygonifolia).

The outer row of sand dunes had a distinct and characteristic vegetation. The sea sand reed (Ammophila arenaria) was the most important and abundant plant and its persistence and habit of growth enabled it to successfully combat the shifting sands of the dunes. It gave the first tinge of green to 
this region in spring and its lines of sprouts from the underlying roots broke the force of the winter winds and prevented the sand from drifting to any great extent. Totally different in appearance from the grass, another plant, the seaside golden-rod (Solidago sempervirens) was second in importance. All during the summer months, the large tufts of fleshy leaves were very conspicuous and later the heavy sprays of yellow blossoms were quite showy. Scattered all through the vegetation created by the previous plants we found the little sand hugging sea spurge. On the bay side of the dunes there were occasional patches of beach pea (Lathryrus maritimus). This plant constituted a prominent element with its tangled stems, bright flowers and noisy pods.

On the area between the first line of dunes and the margin of the dune formation there were a number of important groups. In the first one large masses of bayberry (Myrica carolinensis) occurred at regular intervals with occasional plants almost at the foot of the first line dunes. Another important shrub mixed with the bavberry was beach plum (Prunus maritima). Its dense masses of white flowers were very showy in the spring. The fruiting propensities of the plant however, were variable, some were loaded with plums and others bore but few. Little of the fruit ripened as people were well acquainted with its value in making jam and jelly.

Other larger areas were inhabited extensively by beach heather (Hudsonia tomentosa). Dull and inconspicuous throughout most of the year, it stood out in strong contrast to the sand when it was covered with yellow flowers in the spring. In this group there were also frequent plants of beach pin weed (Lechea maritima) and patches of sea coast joint weed (Polygonella articulata:, the latter being much more numerous than conspicuous. The cactus (Opuntia opuntia) occurred here, sometimes forming plants three feet across. In this band was found the only fungus of noticeable importance in the whole area. This was the earth star (Geaster sp.) which appeared late in the summer in sheltered sandy places where other vegetation was scanty or lacking. In the deep sand only the spongy, spore 
bearing portion was pushed above the surface of the sand by the hygroscopic action of the reflexed peridermium.

The third important group in this section was found in the low, wet spots in which no collecting for insects was done.

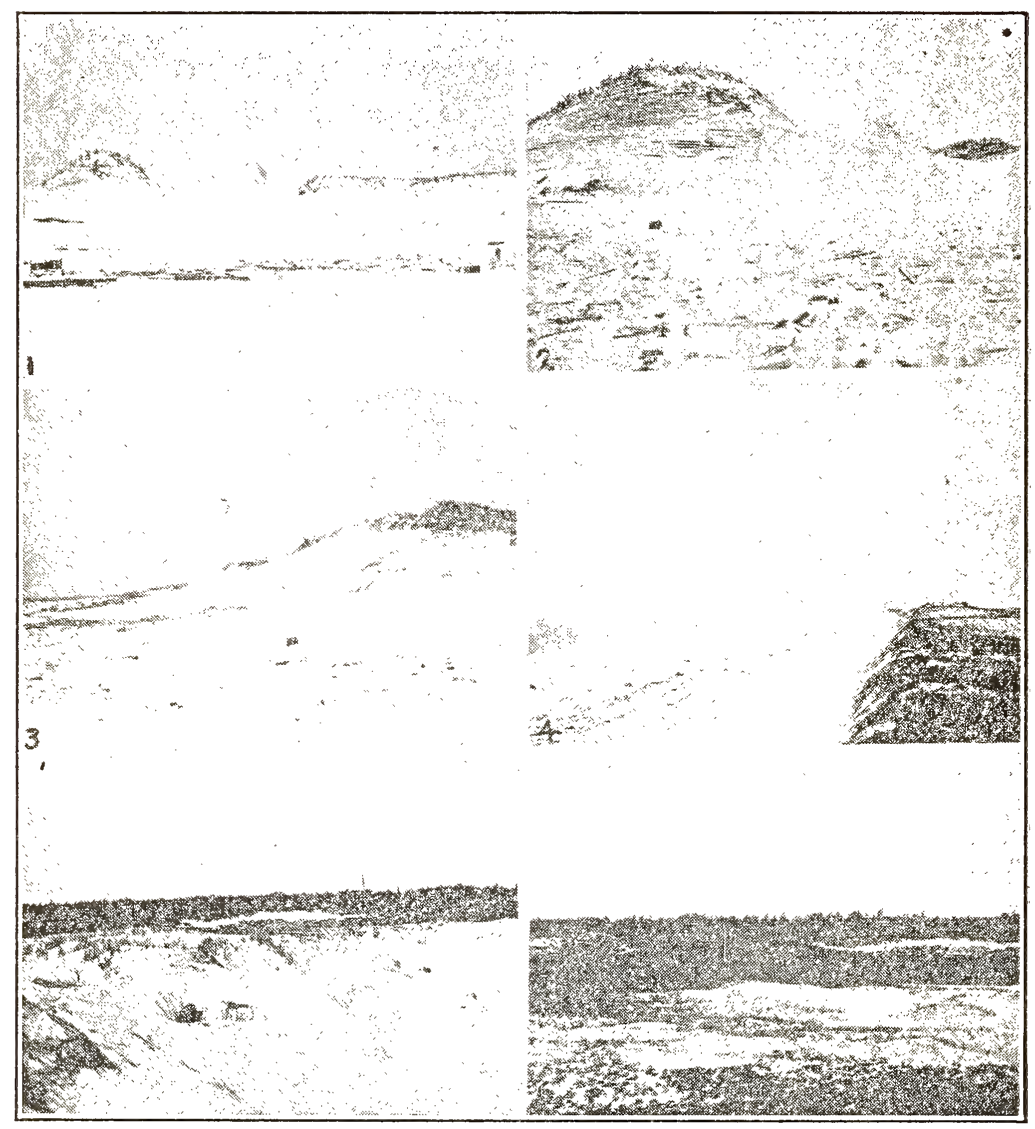

Fig. 2. Views of the surveyed area. 1,2, 3, 4, views along the seashore showing the dunes and their sparse vegetation. 4,5 , views looking across the surveyed area showing the low vegetation and the many, open, sandy areas.

These low spots were almost impenetrable thickets of green brier (Smilax rotundifolia), tall blackberry (Rubus argutus), poison ivy and glossy rose (Rosa virginiana). With these there was a generous sprinkling of sheep laurel (Kalmia angustifolia), 
tall blueberry (Vaccinium corymbosum), bayberry (Myrica carolinense) and scrubby red cedar (Juniperus virginiana).

From the edge of the dune formation to the bay shore, the vegetation was quite uniform. A major portion of the area which comprised all of the high sandy ground on which the collecting was done, was covered with beach heather. As near the dunes, Lechea maritima was occasional here. A few patches of blue toad flax (Linaria canadensis) were found here in spots with the most underground moisture.

As the bay shore was approached this Hudsonia flora was diluted with various grasses in increasing amounts until it disappeared and a new type of vegetation took its place. In the beginning this transition was slow but close to the bay shore the change was rapid and other species came in. Some of the plants in this last area were undoubtedly "ballast plants." The beach goldenrod reappeared here in great profusion but due to severe insect attacks, it did not bloom freely. Wild pepper grass (Lepidium virginicum), sheep sorrel (Rumex acetosella), sea burdock (Xanthium canadense), goose foot (Chenopodium polyspermum), beggar ticks (Bidens connata), salt marsh Heabane (Pluchea camphorata), bush goldenrod (Euthamia graminifolia) and primrose (Oenothera biennis) more or less evenly mixed made up the major portion of the dry ground flora close to the bay shore. In addition there were a few patches of great bind weed (Convolvulus sepium) with its showy pink flowers. In the moist spots there were a few bushes of marsh elder (Iva fructescens) and speckled alder (Alnus incana).

In the lower portions of this area we found the same group of marsh loving plants as near the ocean shore but with some additions. There were also several small, wild cranberry bogs (Oxycoccus marcocarpus). In other spots there were patches of the sundews "Drosera rotundifolia and Drosera filiformis. Lycopodium chapmani was quite frequent in wet spots. The narrow leaved sundrop (Kneiffia linearis) was most plentiful along the margins of these moist areas. 
The Insects of the Surveyed Area. ${ }^{1}$

Neuroptera: Chrysopidæ 1, Myrmeleonidæ 1, Total 2. Isoptera: Termitidæ 1, Total 1.

Odonata: Agrionidæ 1, Libellulidæ 1, Total 2.

Thysanoptera: Thripidæ 1, Total 1.

Homoptera: Aphididæ 2, Membracidæ 2, Fulgoridæ 6, Cercopidæ 2, Tettigoniellidæ 4, Cicadellidæ 13, Total 29.

Hemiptera: Pentatomidæ 6, Lygæidæ 12, Coreidæ 3, Tingitidæ 1, Reduviidæ 2, Phymatidæ 1, Anthocoridæ 1, Miridæ 8, Ochteridæ 2, Total 36.

Orthoptera: Acridiidæ 10, Locustidæ 4, Gryllidæ 3, Total 17.

Coleoptera: Cicindellidæ 2, Carabidæ 7, Silphidæ 1, Staphylinidæ 7, Phalacridæ 2, Coccinellidæ 7, Dermestidæ 2, Histeridæ 7, Nitidulidæ 1, Latridiidæ 2, Dascyllidæ 1, Elateridæ 4, Buprestidæ 2, Lampyridæ 3, Malachidæ 2, Cleridæ 1, Scarabaeidæ 4, Cerambycidæ 3, Chrysomelidæ 19, Mylabridæ 1, Tenebrionidæ 6, Melandryidæ 1, Mordellidæ 2, Anthicidæ 1, Meloidæ 1, Thynchitidæ 1, Otiorynchidæ 1, Curculionidæ 7, Calandridæ 2, Anthribidæ 1, Total 101.

Lepidoptera: Nymphalidæ 5, Lycaenidæ 2, Pieridæ 3, Hesperidæ 1, Syntomidæ 2, Arctiidæ 1, Noctuidæ 12, Hypenidæ 1, Geometridæ 1, Pyralidæ 5, Oecophoridæ 1, Blastobasidæ 1, Total 45.

Hymenoptera: Tenthredinidæ 1, Vipionidæ 9, Braconidæ 6, Ichneumonidæ 18, Cynipidæ 2, Pteromalidæ 1, Callimonidæ 1, Eurytomidæ 1, Chalcididæ 2, Platygastridæ 1, Bethylidæ 1, Mutillidæ 1, Psammocharidæ 5, Vespidæ 1, Sphecidæ 3, Bembecidæ 2, Apoidea 4, Nomalidæ 1, Hylaeidæ 1, Anthophoridæ 1, Colletidæ 3, Xylocopidæ 1, Ceratinidæ 2, Apidæ 3, Formicidæ 23, Total 96.

Diptera: Tipulidæ 4, Chironomidæ 6, Culicidæ 2, Mycetophilidæ 1, Cecidømyiidæ 1, Bibionidæ 4, Tabanidæ 3, Bombyliidæ 1, Therevidæ 3, Asilidæ 3, Dolichopodidæ 4, Empididæ 5, Lonchopteridæ 1, Pipunculidæ 2, Syrphidæ 6, Conopidæ 1, Tachinidæ 1, Sarcophagidæ 2, Muscidæ 3, Anthomyidæ 9, Borboridæ 1, Sapromyzidae 6, Micropezidæ 1, Trypetidæ 1, Sepsidæ

${ }^{1}$ Numbers following family names indicate number of species collected. 
1, Ephydridæ 3, Oscinidæ 10, Drosophilidæ 1, Agromyzidæ 5, Total 93.

Notes on Certain Species of Insects.

Neuroptera. The two species in this order were Brachynemurus abdominalis Say, which was common $(8-5 ; 10-24 ; 11-8)$ and Chrysopa oculata Say (6-16; 8-20).

Isoptera. Termes flavipes Koll. was found early in the season (5-15) in rotten wood and wingless termintes (5-29) at the water line of the ocean.

Odonata Erythrodiplax berenice Dru. was common along the shore (7-15; 8-5) and also Enallagma durum Hagen (7-15; $8-5 ; 9-8 ; 9-26)$ the larvæ of the former living in salt water according to Smith.

Homoptera Plant lice were observed on seaside goldenrod and Lactua sp. Aside from Phlepsius fascipennis Van D., which occurs on salt marshes and which was collected July 15, nothing unusual or characteristic of the locality was observed. Several species which do not appear to have been previously recorded from New Jersey were collected and these are as folflws, Cixius basalis Van D. (7-15), Myndus fulvus Osb. (7-15)., Megamelanus elongatus Ball (6-16), Bostora nasuta Ball (8-5). Platymetopius cuprescens Osb. (8-20, 9-26), Thamnotettix nigrifrons (Forbes) (6-16, 7-15, 10-24).

Hemiptera. The Pentatomidæ, Lygaeidæ and Miridæ were the best represented families. In the Pentatomidæ, Aethus obliquus Uhl. was found May 7 in the sand under Hudsonia and Thyanta custator Fab. was plentiful from May to September. In the Lygaeidæ, Orthlomus ocolopa Uhl was collected (7-15, 9-26 and Blissus leucopterus var. arenarius Barb. (5-7, 7-15-9-26. In the Coreidæ, Harmostes reflexulus Say and Corizus lateralis Say were plentiful throughout the season. Corythucha marmorata Uhl. was noted on seaside goldenrod and this nearness to the ocean may explain its occasional presence in "wash up." Tetraleps insidiosus (Say) was swept from beach pea by the thousands during September and Ochterus banksi Barb. which appears to like the seashore was collected on July 2 . 
Orthoptera. In this order Trimerotropis maritima (Harris) which is almost exclusively a beach species was plentiful from the middle of July to the end of October. Psinidia fenestralis (Serv.) was plentiful in the area from August 5 to September 26 as was Melanoplus femur-rubrum from the first week of September to the end of October. In the Gryllidæ, Gryllus assimilis Fab. form luctuosus Serv. was taken in various parts of the area except the seashore from May 7 to the last week of October, and was present in large numbers under a dead horse-shoe crab along the bay shore. Oecanthus quadripunctatus Beut. was numerous from August 8 to September 26 and occurred plentifully on seaside golden rod flowers on the latter date.

Coleoptera. Cicindela dorsalis Say, a seashore species was collected (7-15) on the beach. Other species taken on the beach were Pasimachus sublævis Beauv. (5-7), Panagceus crucigerus Say (7-15), Pinacodera limbata Dej. (7-15), Anisodactylus rusticus Say (5-7 to 10-24) along the seashore and also in sand under Hudsonia during the early portion of the season. All of the foregoing are members of the Carabidæ. Silpha surinamensis Fab. was collected under a dead horse-shoe crab on August 5 as were also Creophilus villosus Grav. and Tympanophorus puncticollis Er. Staphylinus prcelongus Mann was found along the seashore together with Diochus thoracicus Csy. on June 16. Seven species of Coccinellidæ were present in the parts of the area covered by vegetation. Dermestes caninus Germ. was collected under a dead horse-shoe crab on August 5 along the shore and in other parts of the area on September 8. Dermestes frischi was found along the shore on May 29. In the Histeridæ, Saprinus fraternus Say which occurs throughout the state was found along the ocean front (5-29, 7-2); Saprinus pennsylvanicus occured under a dead horse-shoe crab (8-5) together with Hister abbreviatus Fab. Hister arcuatus Say was collected along the shore (7-2), Saprinus mancus Say in sand under Hudsonia (5-7) and Hister obtusatus Harris along shore (6-16). Other species found along the seashore were Polyphylla variolosa Hentz (7-15), Collops nigriceps Say (7-2), Monoxia puncticollis Say (7-2), Epitragus arundinis Lec. (8-5, 8-20), Ephalus latimanus Lec. (5-7, 6-15), 
Phaleria testacea Say (5-29, 7-15), and Sphenophorus venatus Say (9-8).

Galerucella kalmice Fall was collected under seaweed along the bayshore (5-29) and along the seashore (6-15). Trirrhabda virgata Lec. was noted seriously injuring the leaves of seaside goldenrod and marsh elder, being present from July 2 to September 26. Stratocgus antceus came to our bait of molasses and fusel oil on the night of September 1 and previous to this time, many dead specimens were noticed in various parts of the area.

Lepidoptera. Many interesting species were observed, the most common being Nomophila noctuella D. \& S. (5-29 to 10-24), Syneda graphica (5-7 to 8-20), Ommatostola lintneri Grt. visiting goldenrod flowers (9-26), Euxoa detersa Wlk. very common on goldenrod flowers (9-26), Pieris rape which was plentiful along the bay shore (7-15 to 9-26), and Heodes hypophleas Boisd. which occurred from May 7 to May 29.

Hymenoptera. As most of our Hymenoptera were not identified beyond genera, it is impossible to mention more than a few of the outstanding species. Galls of Solenozopheria vaccinii were present on blueberry stems. Psammochares philadelphicus Le P. was collected along the seashore (7-15) and in other sections (7-20, 8-20). Pompiloides marginatus Say occurred along shore (9-26) and in other areas (7-15, 8-20). Polistes pallipes Le P. was taken from May 15 to October 24 and Colletes americanus Cress. was plentiful on goldenrod flowers (9-26). Bremus bimaculatus Cress. was noted visiting beach pea flowers on June 16. Among the ants Dolichoderus plagiatus pustulatus Mayr. var. beutenmuelleri Wheeler. Formica pallide-fulva schaufussi Mayr var. incerta Emery and Lasius niger Linn. var. neoniger Emery were common throughout the season. Camponotus caryce Fitch was collected May 29 from an old cone of Pinus rigida where it appeared to be nesting.

Diptera. Some ninety-three species were collected, many of which it is impossible to mention on account of a lack of space. The following species were collected along the seashore.

Tipula perlongipes Johnson (7-15), Neopogon argenteus Say a sand dune species (8-5), Villa shawi John. (9-26, 10-24), Psilo-, cephala morata Coq. (6-16), Coloboneura inusitata Mel. (7-2). 
Fucellia maritima Hal. was plentiful both on the seashore and the bayshore from April 17 to October 24. Sarcophaga pachyprocta Parker was plentiful in the area at all times and was bred from puparia collected on the surface of the sand between the sand dunes. Other species plentiful in other parts of the area were Bibio albipennis Say (5-15, 5-29), Epomyia rufiventris Loew (7-15, 9-8), Cœnosia nudiseta Stein (6-16 to 9-26), Scatella lugens Lw. (5-7 to 7-15), Hippelates subvittatus Mall. (6-16 to 9-26), Botanobia frit Linn. Rhicnossa parvula Loew (5-29 to 7-2), and Toxomerus marginatus Say 6-16 to 10-24). Visiting goldenrod flowers on September 26 and present at previous times were Stomoxys calcitrans Lw. Phormia regina Meigen, Eristalis aneus Scop. and Eristalis transversus Wied. Early in the season land breezes brought Aedes cantator Coq. and later Aedes sollicitans Wlk.

\section{SUMMARY.}

Insects of the Coast.

\begin{tabular}{|c|c|c|}
\hline Order & Number of Species & Percent of total \\
\hline Neuroptera & 2 & \\
\hline Isoptera & I & I \\
\hline Odonata & 2 & \\
\hline Thysanoptera & I & \\
\hline Homoptera & 29 & 7 \\
\hline Hemiptera & 36 & 8 \\
\hline Orthoptera & I7 & 4 \\
\hline Coleoptera & IOI & 24 \\
\hline Lepidoptera & 45 & II \\
\hline Hymenoptera & 96 & 23 \\
\hline \multirow[t]{4}{*}{ Diptera } & 93 & 22 \\
\hline & 423 & 100 \\
\hline & Types of Food Habits & \\
\hline & Number of Species & Per cent of total \\
\hline Phytophagous & I 89 & 45 \\
\hline Saprophagous & IIO & 26 \\
\hline Harpactophagous & 58 & I4 \\
\hline & 47 & II \\
\hline \multirow[t]{3}{*}{ Pollen feeders, misc. spp. } & I9 & 4 \\
\hline & - & - \\
\hline & 423 & 100 \\
\hline
\end{tabular}


As indicated above, with respect to the number of species, the Coleoptera, Hymenoptera and Diptera each supplied an almost equal amount and these orders are followed in turn by the Lepidoptera, Hemiptera, Homoptera and Orthoptera. Concerning the types of food habits, these being based for the most part on the predominating larval habits of the families regardless of numerical abundance (and with the disadvantages of this method fully in mind) 45 per cent of the species present can be classed as phytophagous, 26 per cent saprophagous, 14 percent harpactophagous and 11 per cent parasitic and it is assumed that similar ratios will be found in other coast sections where similar conditions prevail. 


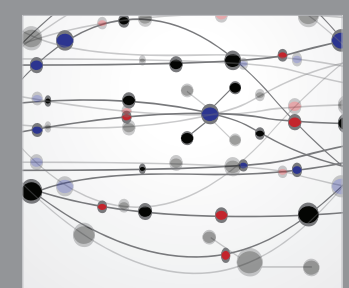

The Scientific World Journal
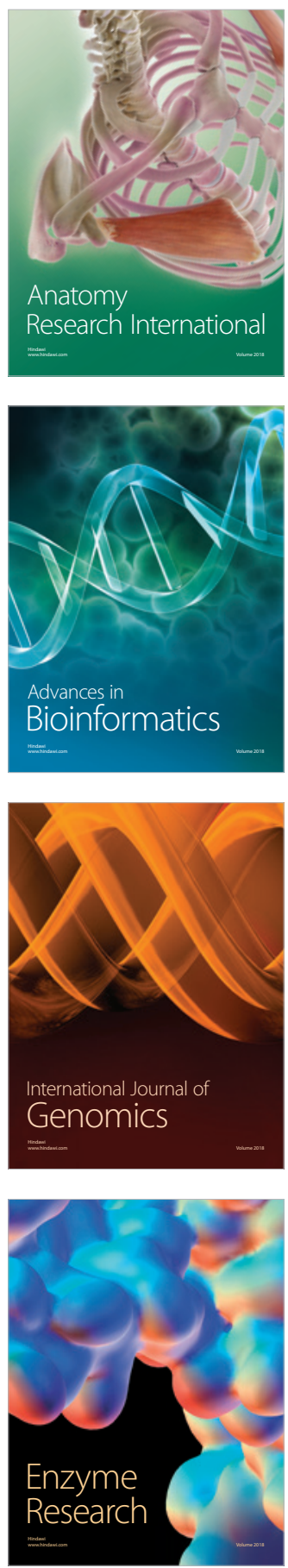
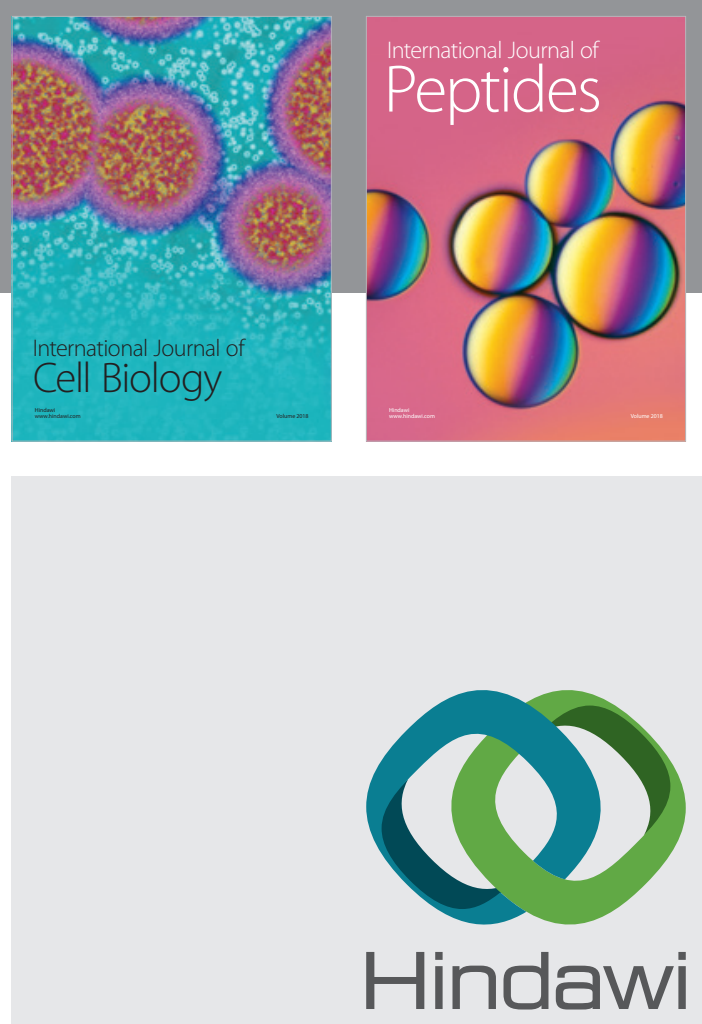

Submit your manuscripts at

www.hindawi.com
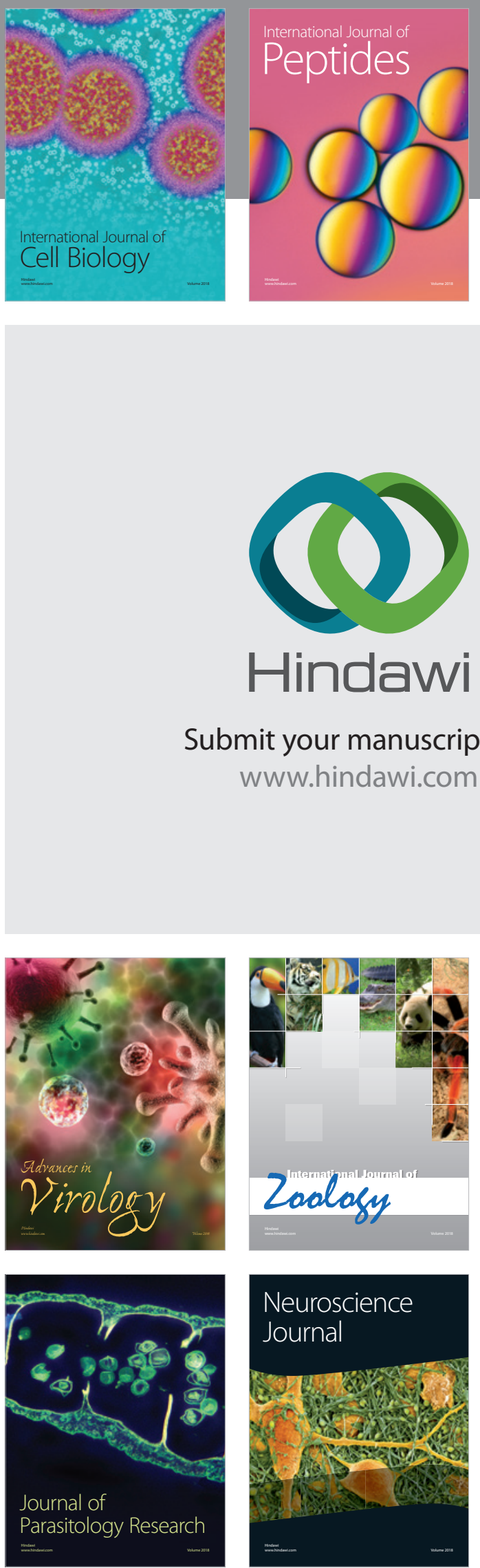
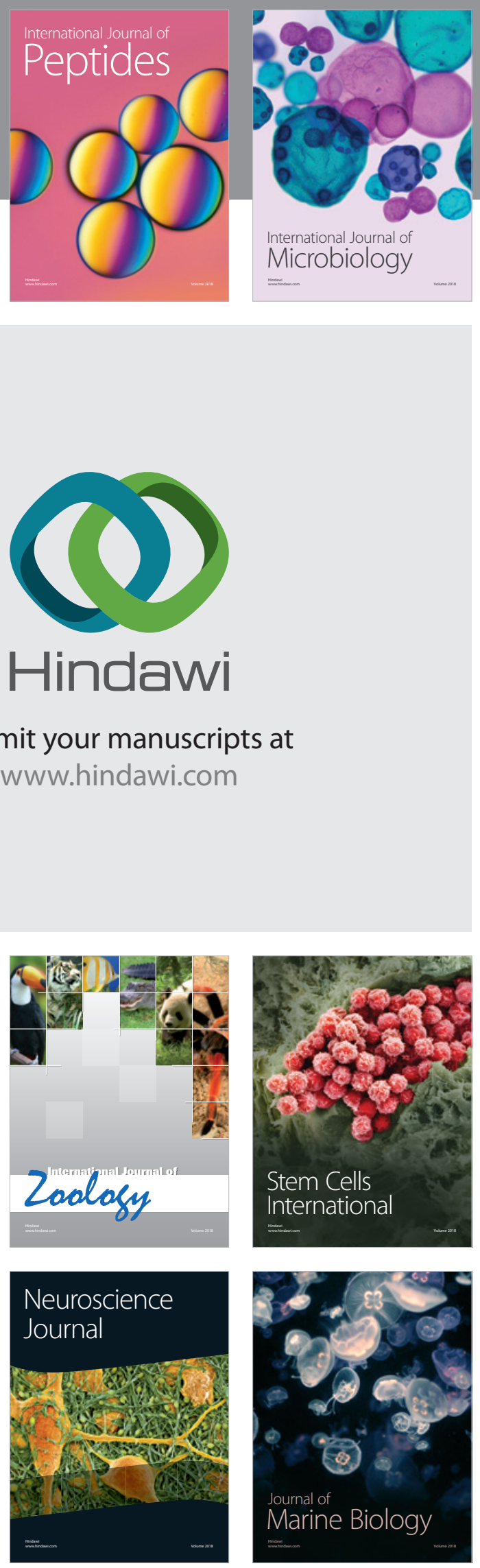
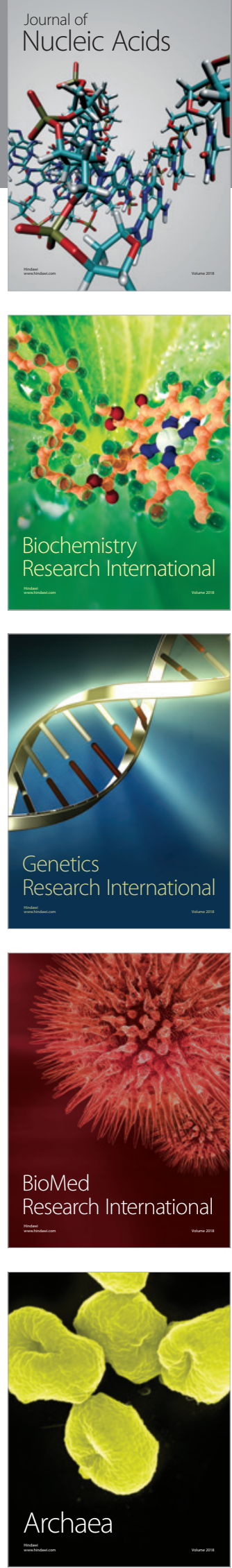